ENTREPRENEURSHIP AND SUSTAINABILITY ISSUES

ISSN 2345-0282 (online) http://jssidoi.org/jesi/ 2020 Volume 8 Number 1 (September)

http://doi.org/10.9770/jesi.2020.8.1(56)
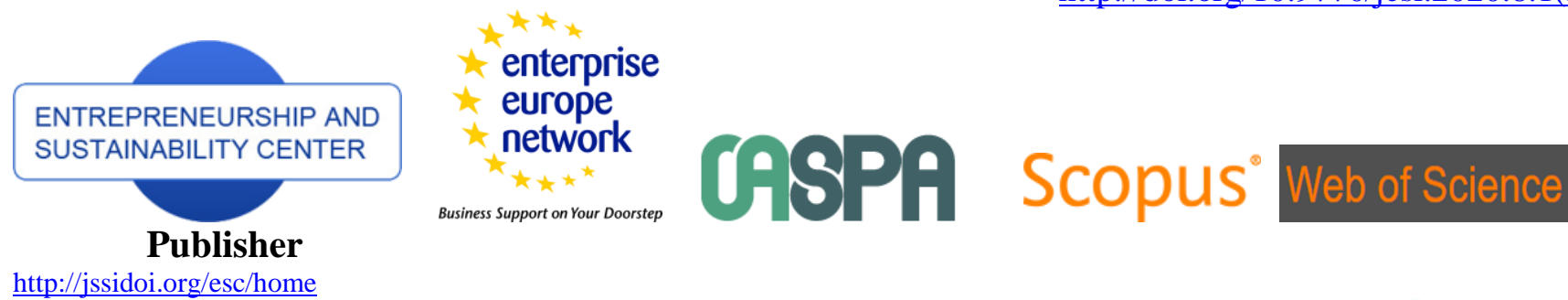

http://jssidoi.org/esc/home

1 Clarivate

Analytics

\title{
IS EDUCATION OR REAL GDP PER CAPITA HELPED COUNTRIES STAYING AT HOME DURING COVID-19 PANDEMIC: CROSS-SECTION EVIDENCE?
}

\author{
Hatem Akeel ${ }^{1}$, Haitham Khoj ${ }^{2}$ \\ ${ }^{1}$ Finance department, College of Business and Administration (CBA), University of Business and Technology (UBT), Jeddah \\ 21448, Kingdom of Saudi Arabia \\ ${ }^{2}$ Economics department, King Abdulaziz University, Jeddah, Kingdom of Saudi Arabia \\ E-mails:.'‥akeel@ubt.edu.sa; ${ }^{2}$ hkhoj@kau.edu.sa
}

Received 15 March 2020; accepted 30 June 2020; published 30 September 2020

\begin{abstract}
This paper is evaluating whether education or the standard of living in a country helped citizens to stay at home during COVID19 pandemic. The study implemented a cross-sectional regression on Google mobility trend reports as of 29th March, 2020 which include the mobility trends in retail and recreation, grocery and pharmacy, park, transit station, workplace and residential areas along with real GDP per capita as a proxy for standard of living and Education Index to approximate the level of education. The cross-sectional regression included 123 countries as a sample for the study. The study found that education index, park mobility trends and workplace mobility trends were significate variables in explaining the changes in residential area. However, real GDP per capita was not significate. The study concluded that standard of living is not a significate variable in changing the percentage of people who stayed at home. Moreover, education index has a negative impact on staying at home. Meaning, for each one-point increase in education index, the percentage change for citizens staying at home decreases by 0.087 . Although, our result indicates that individual's education has a negative effect, this result can be explained by the decline of political trust in demarcate government were education index is high.
\end{abstract}

Keywords: COVID-19; Coronavirus; Education; Real GDP Per Capita; Cross-Sectional Regression; Standard of Living

Reference to this paper should be made as follows: Akeel, H., Khoj, H. 2020. Is education or Real GDP per capita helped countries staying at home during COVID-19 pandemic: cross-section evidence? Entrepreneurship and sustainability Issues, 8(1), 841-852. http://doi.org/10.9770/jesi.2020.8.1(56)

JEL Classifications: E00, I00

\section{Introduction}

According to the world health organization (WHO) coronavirus disease (COVID-19) was reported from Wuhan, China, on 31st December 2019 for the first time. COVID-19 is one of the large family of other coronavirus that cause sickness ranging from mild common cold to more serve diseases. For example, two coronavirus that have identified in humans are the Middle East respiratory syndrome (MRES-COV) and severe acute respiratory syndrome (SARS-COV). As we are writing this paper, COVID-19 is spreading in more than 185 countries affecting more than two million people all over the world. Because of the fear of sharp increase of cases of COVID-19, many countries implemented number of procedures and policies to slowdown the spreading of the 


\section{ENTREPRENEURSHIP AND SUSTAINABILITY ISSUES}

ISSN 2345-0282 (online) http://jssidoi.org/jesi/

2020 Volume 8 Number 1 (September)

http://doi.org/10.9770/jesi.2020.8.1(56)

virus. Past studies have shown that epidemic infection had a negative impact on the economics activity such as H1N1 (Rassy and Smith 2013).

Beyond the tragic effect of coronavirus on the human lives, the pandemic has a direct economic effect. Families are losing their loved ones at the same time the economic climate are now becoming unbearable. The working population works from home and most workplaces are shutting down laying off their employees. According to the Department of Labor (DOL) in the US, 26 million people are filling for unemployment benefits. The stocks market around the world is trembling and this health crisis is now a world-wide global crisis. The economic impacts on various countries varies, countries such as Germany are having most of their cases absorbed by testing and good governance. However, low income economies like Bangladesh who do not have the needful resource are globe's most vulnerable populations (DOL, 2020).

Essential government measures like shutting down factories in China or closing retail shops in Italy might indicate that a recession is anticipated. According to General Administration of Custom in China, manufacturing and service sector in February has recorded a drop of $80 \%$ on automobile sales, a fall in exports by $17.2 \%$ between January and February. China is a crucial producer of inputs that are imported by most countries. The decline in exports is because of the shutdown of the factories. Also, most retail shops around the world experienced a drop in demand due to the movement restrictions required to curb the spread of coronavirus (GACC, 2020).

The spread of COVID-19 into the United State, Europe and other countries has led to legislative measures. Japan and Europe are already facing a recession because of their high dependence on international trade and weak fourth quarter performance. The Organization for Economic Co-operation and Development (OECD) has drawn a prediction that the outbreak of COVID-19 will reduce global economic from $2.9 \%$ to $2.4 \%$ (OECD, 2020).

The level of education or human development is an important factor in united nation development program (UNDP) framework to assess the readiness of pandemic crisis like COVID-19 (see Figure 1). In Figure 1, Asianpacific countries are divided into different clusters ranging from 1 to 5. Cluster 1 includes China, South Korea, Hong Kong and Singapore where they have high human capital. On the other hand, cluster 5 have mostly medium level of human development which includes countries like Fiji, Bhutan, Tonga, Micronesia, Vanuatu, Nepal, Solomon Islands and Afghanistan.

By looking to the recent OECD forecasts, most worldwide countries are interconnected extremely with China. Countries like Japan, Australia and South Korea will face adverse downward in GDP growth. The spread rate of the disease in the European countries and the United States has led to the adoption of restrictive responses. These restrictive responses will have adverse effects on economic activities risking a loss of billions of dollars. The United Nation (UN) has projected that lowest levels of about $-5 \%-15 \%$ in foreign direct investment (FDI) are anticipated in multinational cooperation around the world. Low income countries in Africa like Uganda and Nigeria are not immune from the economic losses from this outbreak. A quarter of Uganda`s imports come from China and Nigeria depends on particular supplies, such as groceries from China. Even South Africa faces to lose over $\$ 28$ million that is spent by Chinese tourists. 
ENTREPRENEURSHIP AND SUSTAINABILITY ISSUES

ISSN 2345-0282 (online) http://jssidoi.org/jesi/ 2020 Volume 8 Number 1 (September) http://doi.org/10.9770/jesi.2020.8.1(56)

Figure 1. Asia-pacific countries spread and responses of COVID-19 taking in consideration the level of human development and the degree of value chains integration

\begin{tabular}{|c|c|c|c|c|c|}
\hline & CLUSTER 1 & CLUSTER 2 & CLUSTER 3 & CLUSTER 4 & CLUSTER 5 \\
\hline & $\begin{array}{l}\text { Very high to high } \\
\text { human development, } \\
\text { advanced } \\
\text { manufacturing } \\
\text { value chains }\end{array}$ & $\begin{array}{l}\text { Mostly high or } \\
\text { medium human } \\
\text { development, } \\
\text { integration into } \\
\text { value chains }\end{array}$ & $\begin{array}{l}\text { Wide range of } \\
\text { income and } \\
\text { development levels, } \\
\text { reliance on natural } \\
\text { resource exports }\end{array}$ & $\begin{array}{l}\text { Medium to high } \\
\text { human development, } \\
\text { relatively less trade } \\
\text { integration }\end{array}$ & $\begin{array}{l}\text { Wide range of } \\
\text { human development } \\
\text { levels, LDCs and } \\
\text { SIDS }\end{array}$ \\
\hline $\begin{array}{l}\text { Spread of the } \\
\text { pandemic and } \\
\text { responses }\end{array}$ & $\begin{array}{l}\text { Pandemic's early } \\
\text { onset, focus on rapid } \\
\text { containment, extensive } \\
\text { stimulus packages, signs } \\
\text { of early recovery }\end{array}$ & $\begin{array}{l}\text { The "second wave" } \\
\text { of the pandemic, } \\
\text { stimulus packages and } \\
\text { containment measures }\end{array}$ & $\begin{array}{l}\text { Different degrees of the } \\
\text { spread of the pandemic } \\
\text { and wide variety of } \\
\text { responses }\end{array}$ & $\begin{array}{l}\text { Late wave of the } \\
\text { pandemic, extensive } \\
\text { containment measures, } \\
\text { massive public health } \\
\text { risks }\end{array}$ & $\begin{array}{l}\text { Relatively isolated and } \\
\text { potentially less affected } \\
\text { by the pandemic, but } \\
\text { public health risks due to } \\
\text { low capacities }\end{array}$ \\
\hline $\begin{array}{l}\text { Level of human } \\
\text { development }\end{array}$ & $\begin{array}{l}\text { Very high or high human } \\
\text { development }\end{array}$ & $\begin{array}{l}\text { Ranges from very high } \\
\text { to medium human } \\
\text { development }\end{array}$ & $\begin{array}{l}\text { Wide range from very } \\
\text { high to low human } \\
\text { development }\end{array}$ & $\begin{array}{l}\text { High and medium human } \\
\text { development }\end{array}$ & $\begin{array}{l}\text { Wide range of human } \\
\text { development levels, but } \\
\text { mostly medium level }\end{array}$ \\
\hline $\begin{array}{l}\text { Degree } \\
\text { of global } \\
\text { value chains } \\
\text { integration and } \\
\text { trade }\end{array}$ & $\begin{array}{l}\text { Highly integrated in } \\
\text { advanced manufacturing } \\
\text { value chains }\end{array}$ & $\begin{array}{l}\text { Integrated in various } \\
\text { manufacturing value } \\
\text { chains }\end{array}$ & $\begin{array}{l}\text { Forward linkages } \\
\text { through supply of natural } \\
\text { resources }\end{array}$ & $\begin{array}{l}\text { Lower degree of trade } \\
\text { openness }\end{array}$ & $\begin{array}{l}\text { Small open economies, } \\
\text { high degree of imports }\end{array}$ \\
\hline
\end{tabular}

Source: United nation development program - The Social and Economic Impact of Covid-19 in the Asia-Pacific Region

Countries around the world learned their lesson to be prepared for the next outbreak. Avoiding economic and health damage of similar outbreak can start by building the process and procedure to deal with infectious disease crisis. Sands, El Turabi, Saynisch, and Dzau (2016) found that the ignorance of infectious disease crisis has not been taking seriously, although infectious diseases have been threatening the global security for a long time. Infectious disease danger and threat have been underestimated among human lives and livelihoods, which led us to be unprepared for any outbreak caused by those diseases. Additionally, the authors urge countries to be prepared for such an outbreak and the state that unity between nations is very important to face an upcoming outbreak.

Morin, Kinzig, Levin, and Perrings (2018) differentiate between the duration of infectious diseases to two categories. The first category is a short-term illness where imposing social distancing can be socially optimal by increasing the life cost of the illness. However, in the second category where a disease is extremely infectious, it may not be optimal to encourage social distancing by dropping the cost of disease. Additionally, they concluded that society would prefer less time with a stronger epidemic than longer time with an epidemic of lower intensity. So, it is important to understand why societies prefer short time pandemics rather than long term epidemics and to evaluate if it is because of the level of education in the society or real GDP per capita that led to this finding.

Many factors affected the public's reaction to the COVID-19 pandemic, but the roles of education and real GDP per capita cannot be ignored. In this study, we want to examine if education or real GDP per capita played a role in different countries in staying at home during COVID-19 Pandemic. This study contributes the first COVID-19 paper that investigate which of the two variables education or real GDP per capita were significate in implementing lockdown and isolation. 


\section{ENTREPRENEURSHIP AND SUSTAINABILITY ISSUES}

ISSN 2345-0282 (online) http://jssidoi.org/jesi/

2020 Volume 8 Number 1 (September)

http://doi.org/10.9770/jesi.2020.8.1(56)

\section{Literature Review}

In the following sections we will review previous studies in ineffectual diseases and their economic ramification. Studies covered different area of the impact of the ineffectual disease on countries economics. Our study is the first study that examine stay home orders and link it to real GDP per capita and the level of education in different countries during COVID-19 Pandemic.

The importance of education and real GDP per capita was discussed in many public health studies investigating different approaches. For example, according to Nakamura (2016) people with higher income and higher education were to follow healthy diets and follow recommendation by health officials. This study indicates the behaviour of individuals depends on two important factors which are education and income. Thus, including education and real GDP per capita may explain any government policy that's related to individual decision.

Similarly, Davino et. at. (2016) investigated people's reaction in environmental policies in developed and developing countries, precisely, when governments impose new regulation that effect people to change their habit for public health emerge. The authors mainly include two variables that might affect people's reaction, GDP per capita and education. They concluded that developed countries are more likely to follow new regulations and people have more knowledge of the importance of environmental issues than developing countries.

In addition, Elmawazini el. at (2017) investigated the health gap between developed (OCED) countries and developing (SSA) countries, and globalization can shrink this gap. The authors concluded that globalization shows no significant effect on the health gap between the OECD and SSA countries. However, GDP per capita growth has a significant impact of the health gap between SSA and OECD countries.

Additionally, Abdelhafiz (2020) investigate the knowledge and attitude of people in Egypt in dependence on real GDP per capita, education, rural cities, and age. They found that people with low income, less education, and elderly have less knowledge and attitude to any government policies regarding the COVID-19 pandemic.

Moreover, Fernandes (2020) investigated the economics effect caused by COVID-19 outbreak across countries and industries. Additionally, the study shed light on the global economic costs of COVID-19, and 30 different countries' GDP. The author found that the effect of the current pandemic was underestimated in comprising with SARS in 2003 and financial crisis 2008/2009. Moreover, the study found that it is hard to forecast when the lockdown or stay at home order will end. Also, there is no guideline to follow during the length of a lock down for those countries in the study.

There are other Studies that recently focused in the pandemic outbreak that help to understand the COVID-19 pandemic impacts the countries economically. For example, Suborna (2020) examine the behaviour of macroeconomics activities in case of pandemic. The study includes all economic activities such as supply, demand, investment, trade, inflation (price level), supply chain, exchange rates, financial stability, economic growth, and international cooperation. The author concludes that it is important for every country to reform their economic policy and implementing of lockdown to prevent any difficulties in the future.

Moreover, Zhang et al. (2020) investigated the movement of population and its impact on the spread of COVID19 in China. They found that population movements have statistically significant impact to the disease spread. Travel ban was effective to slow down the spread of the virus. However, the authors found that it would be much helpful if travel ban enforced earlier to prohibit the spread of the disease.

Also, Li, et al. (2020) examine people precaution of containing the disease or keep their normal economic activities during COVID-19 in China. In order to test people perception, they used an online survey with 


\section{ENTREPRENEURSHIP AND SUSTAINABILITY ISSUES}

ISSN 2345-0282 (online) http://jssidoi.org/jesi/ 2020 Volume 8 Number 1 (September) http://doi.org/10.9770/jesi.2020.8.1(56)

randomized controlled trials during the COVID-19. The authors found lower number of confirmed cases has a positive impact on individual's expectation on GDP growth rate. While this cannot be hold on the level of economic recovery, because there is no correlation with their expectations on GDP growth. The authors explained that individual expectations are not updated when new information provided in a randomized controlled trial.

\section{Research objective and methodology}

The cross-sectional data is collected for 123 countries. A descriptive statistic of all variables is shown in Table 1 . Most of the variables are taken from Google mobility data reports. These reports show the percentage change in visits and length of stay at distinctive areas compared to the beginning of 2020 (between January 3rd and February 6th, 2020 - baseline). This baseline between January 3rd and February 6th is compared to March 29th in which most courtiers are on lockdown or advised to the stay at home during the COVID-19 outbreak. The places are categorized into 6 which are retail and recreation, grocery and pharmacy, parks, transit stations, workplaces and residential. China and Iran are not included in the data since Google services are not offered there. The other two variables are real GDP per capita adjusted to inflation and education index for each country. The data for those two variables are taken from the world economic outlook report (2019) and United Nations human development report (2019).

Table 1. Descriptive statistic of all data

\begin{tabular}{|l|c|c|c|c|c|c|c|c|}
\hline & $\begin{array}{l}\text { Retail \& } \\
\text { Recreation }\end{array}$ & $\begin{array}{l}\text { Grocery } \\
\text { Pharmacy }\end{array}$ & Parks & $\begin{array}{l}\text { Transit } \\
\text { Station }\end{array}$ & Workplaces & Residential & $\begin{array}{l}\text { Real GDP } \\
\text { per Capita }\end{array}$ & $\begin{array}{l}\text { Education } \\
\text { Index }\end{array}$ \\
\hline Mean & $-59 \%$ & $-38 \%$ & $-39 \%$ & $-59 \%$ & $-34 \%$ & $16 \%$ & 17831 & 0.6888 \\
\hline $\begin{array}{l}\text { Standard } \\
\text { Error }\end{array}$ & 0.0203 & 0.0204 & 0.0252 & 0.0182 & 0.018065 & 0.006331 & 2005 & 0.01511135 \\
\hline Median & $-64 \%$ & $-36 \%$ & $-41 \%$ & $-61 \%$ & $-36 \%$ & $15 \%$ & 7223 & 0.706 \\
\hline Mode & $-45 \%$ & $-25 \%$ & $-59 \%$ & $-68 \%$ & $-52 \%$ & $15 \%$ & \#N/A & 0.923 \\
\hline $\begin{array}{l}\text { Standard } \\
\text { Deviation }\end{array}$ & 0.22558 & 0.22729 & 0.2796 & 0.2026 & 0.20035 & 0.07022 & 22238 & 0.16759 \\
\hline $\begin{array}{l}\text { Sample } \\
\text { Variance }\end{array}$ & 0.05088 & 0.05166 & 0.0782 & 0.0410 & 0.04014 & 0.00493 & 494561084 & 0.02809 \\
\hline Kurtosis & -0.6177 & 0.05367 & 0.65923 & 0.03902 & -0.72454 & 0.10773 & 3.29715 & -0.54370 \\
\hline Skewness & 0.51590 & -0.13449 & 0.52826 & 0.74724 & 0.28714 & 0.12014 & 1.80936 & -0.49103 \\
\hline Range & 0.92 & 1.18 & 1.38 & 0.86 & 0.87 & 0.38 & 115121 & 0.699 \\
\hline Minimum & $-94 \%$ & $-94 \%$ & $-90 \%$ & $-92 \%$ & $-73 \%$ & $-3 \%$ & $\$ 4414.328$ & 0.247 \\
\hline Maximum & $-2 \%$ & $24 \%$ & $48 \%$ & $-6 \%$ & $14 \%$ & $35 \%$ & $\$ 115,536$ & 0.946 \\
\hline Sum & -72.45 & -46.69 & -47.82 & -72.59 & -41.73 & 19.92 & 2193331 & 84.726 \\
\hline Count & 123 & 123 & 123 & 123 & 123 & 123 & 123 & 123 \\
\hline
\end{tabular}

Source: Compiled by the authors

Retail and recreation category include the percentage change in visits in the beginning of the year compared to March 29th, 2020 for places like museums, cafes, movie theatres, shopping centers, libraries, restaurants and theme parks. All countries endured reduction in visits in this classification. However, Italy had the largest contraction in retail and recreation visits compared to the baseline reaching $-94 \%$ in reduction.

Grocery and pharmacy category include drug stores, grocery markets, farmers markets, food warehouses, specialty food shops and pharmacies. The mobility trends for these places are mixed but mostly negative for most countries. Only 6 countries out of 123 had zero or positive percentage change in visits to grocery and pharmacy compared to baseline which are Belarus, Benin, Trinidad and Tobago, Ghana, Mongolia and Zimbabwe. 


\section{ENTREPRENEURSHIP AND SUSTAINABILITY ISSUES}

ISSN 2345-0282 (online) http://jssidoi.org/jesi/

2020 Volume 8 Number 1 (September)

http://doi.org/10.9770/jesi.2020.8.1(56)

Parks mobility trends surprisingly jumped positively to $48 \%$ in Finland and $43 \%$ in Sweden and $41 \%$ in Belarus compared to the baseline. More people are visiting parks while they should stayed at home in those countries. Moreover, some other countries had a mild percentage change increase by $10 \%, 5 \%, 4 \%$ and $4 \%$, in Benin, Mongolia, Estonia and Tajikistan respectively. The remaining countries had reduction in the percentage of visits compared to the beginning of the year. Google's classification for parks includes public gardens, public beaches, plazas, national parks, plazas, marinas and dog parks.

Transit station category includes subways, buses, train station and public transport is included under transit station category. The percentage change in mobility trends in these places were negative ranging from $-6 \%$ to $92 \%$. While all other sectors have at least one country that reached a percentage change in reduction reaching $90 \%$, the maximum negative percentage change in workplace was in Jorden reaching $-73 \%$ compared to the baseline.

Most countries had a positive percentage change in residential category reaching the maximum of $35 \%$ in Bolivia. Only Belarus and Tajikistan had a percentage change decrease by -2 and -3 respectively (see Figure 2). This variable will show the percentage change of all residential places compared to the baseline.

Real Gross domestic product per person adjusted to inflation (real GDP per capita) is a common variable used to measure the standard of living. The data is collected from the world economic outlook report (2019). It approximates each citizen benefit form overall economy of their country. Education index is collected from the Human Development Report (2018). The index is calculated by taking the average of mean years for adult schooling and expected years of children schooling.

The study is testing whether the standard of living or education were a significate contributor for people to stay at home during COVID-19 pandemic. The paper used real GDP per capita in 2018 as an estimator for the standard of living for the 123 countries. Also, the study used education index taken from the human development report (2019) as an approximation for education level for the 123 countries. To test for that, the study developed a cross sectional regression model for 123 countries as follows:

$$
Y=\alpha+\beta_{1} R R+\beta_{2} G P+\beta_{3} P+\beta_{4} T+\beta_{5} W+\beta_{6} R G D P+\beta_{7} E+\mu
$$

Where Y represent the dependent variable which is the percentage change in residential areas compared to the baseline and, RR is the percentage change in retail and recreation mobility trend compared to the baseline, GP is the percentage change in grocery and pharmacy mobility trend compared to the baseline, $\mathrm{P}$ is the percentage change in parks mobility trend compared to the baseline, $\mathrm{T}$ is the percentage change in transit station mobility trend compared to the baseline, $\mathrm{W}$ is the percentage change in work place mobility trend compared to the baseline, RGDP the real GDP per capita in US dollar, $\mathrm{E}$ is the education index taken from the human development report (2018) and $\mu$ is an error term. RR, GP, P, T, W, RGDP and E are the independent variables. 
ENTREPRENEURSHIP AND SUSTAINABILITY ISSUES

ISSN 2345-0282 (online) http://jssidoi.org/jesi/

2020 Volume 8 Number 1 (September)

http://doi.org/10.9770/jesi.2020.8.1(56)

Figure 2. Percentage change in residential areas compared to the baseline for 123 countries in March $29^{\text {th }}, 2020$

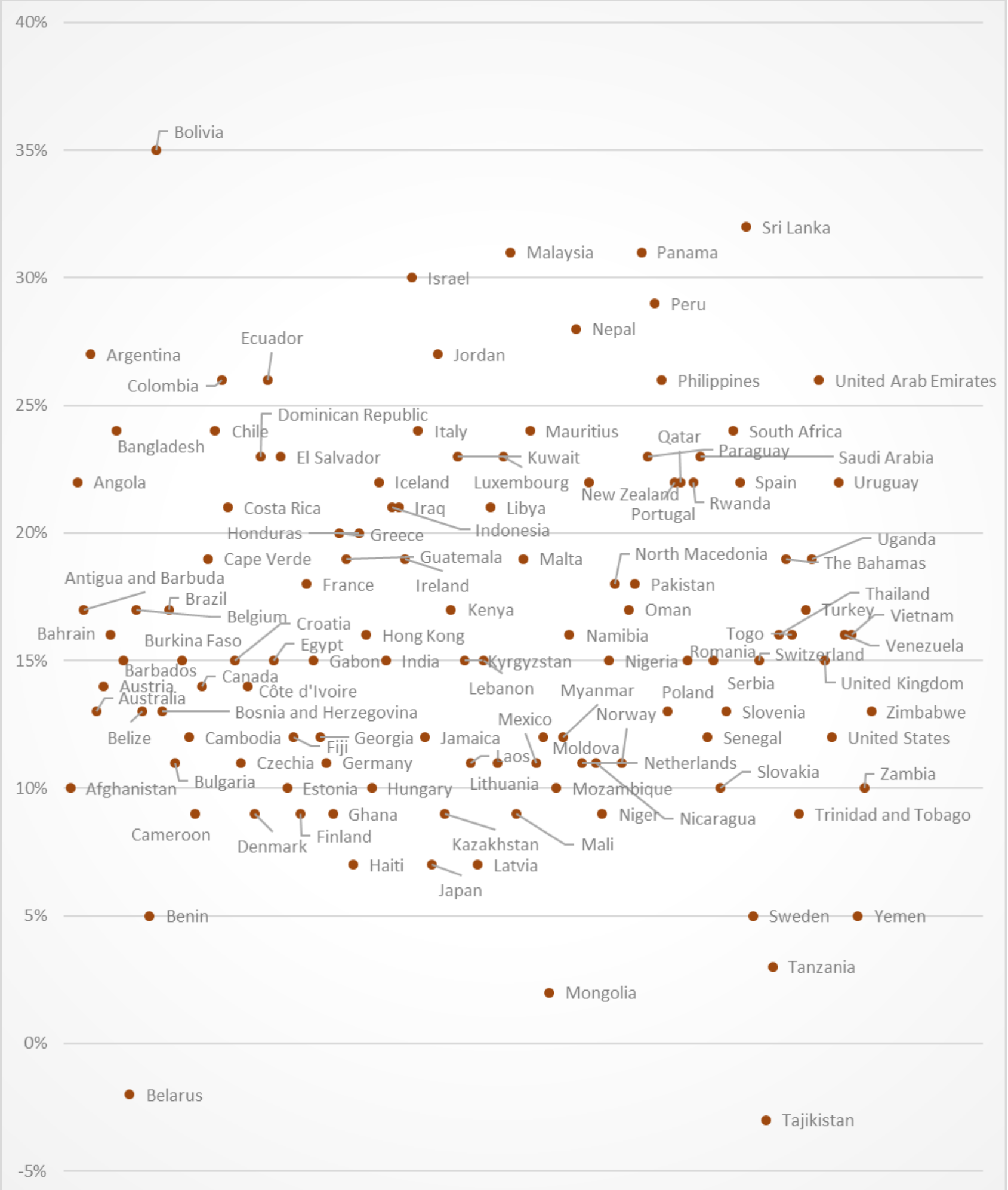

Source: Compiled by the authors 


\section{Results and discussion}

After running the cross-sectional regression model using robust command in Stata application, the result is shown in Table 2. Table 2 shows that only parks, workplaces and education where statistically significate. Those variables can explain the percentage change in residential areas in different countries since COVID-19 pandemic. $\mathrm{R}^{2}$ is $71.2 \%$, which means that $71.2 \%$ of the variation in the residential area during COVID-19 pandemic is explained by the percentage changes in parks, workplaces and education mobility trends. The finding is interesting since it shows that living standard is not a significate factor in explaining the percentage change of people staying at home.

Another interesting finding is that education is a significate variable. However, the coefficient for education is negative which means for each one-point increase in education index, the percentage change for citizens staying at home decreases by 0.0872 . Education is inversely affecting the percentage change in people staying at home during COVID-19 outbreak. The negative effect maybe because of the decline of political trust in demarcate government were education index is high. There is a significate evidence - especially in young people - showing that citizens display lower levels of political trust. Lower political trust can be the reason why citizens are ignoring stay at home orders (Chevalier, 2019). The OLS estimator equation is the following:

$$
\hat{Y}=0.1146+-0.1019 P-0.1985112 W-0.0872 E
$$

Table 2. Cross-sectional regression model results

\begin{tabular}{|c|c|c|c|c|}
\hline & Coefficients & $\begin{array}{l}\text { Robust } \\
\text { Standard } \\
\text { Error }\end{array}$ & t-stat & P-value \\
\hline Intercept & 0.1145864 & 0.0201152 & 5.70 & $0.000 * * *$ \\
\hline $\mathrm{RR}$ & 0.0692686 & 0.0593392 & 1.17 & 0.245 \\
\hline GP & -0.004733 & 0.0491194 & -0.10 & 0.923 \\
\hline $\mathrm{P}$ & -0.1019377 & 0.0192068 & -5.31 & $0.000 * * *$ \\
\hline $\mathrm{T}$ & -0.0654919 & 0.0414065 & -1.58 & 0.116 \\
\hline $\mathrm{W}$ & -0.1985112 & 0.0442529 & -4.49 & $0.000 * * *$ \\
\hline $\mathrm{E}$ & -0.0872348 & 0.0289625 & -3.01 & $0.003 * * *$ \\
\hline RGDP & 0.0000 & 0.00000 & 0.26 & 0.792 \\
\hline $\mathrm{F}(7.115)$ & \multicolumn{4}{|c|}{44.24} \\
\hline Prob $>F$ & \multicolumn{4}{|c|}{0.0000} \\
\hline $\mathrm{R}^{2}$ & \multicolumn{4}{|c|}{$71.26 \%$} \\
\hline Root MSE & \multicolumn{4}{|c|}{0.03877} \\
\hline Observations & \multicolumn{4}{|c|}{123} \\
\hline \multicolumn{5}{|c|}{$\begin{aligned} \text { Notes: } *, * *, \text { and } * * * & \text { denotes statistical significance at } 10 \%, 5 \% \\
& \text { and } 1 \% \text { respectively. }\end{aligned}$} \\
\hline
\end{tabular}

Source: Compiled by the authors

Moreover, workplaces and parks mobility trends have a negative sign which is expected since people who are in park and workplace will not be at home. The model shows that each one-point increase in workplace, the percentage change for citizens who are staying at home decreases by 0.1985 . Also, for each one-point increase in parks, the percentage change for people who are staying at home decreases by 0.1019 .

The model can help governments around the world to design more effective policy that target and limit going to workplaces and parks which ultimately increase the percentage of people staying at home. Not only those variables were significate in the regression model, they were also the highest correlated variables to the dependable variable (residential areas). Table 3 shows the correction matrix of selected variables including parks 


\section{ENTREPRENEURSHIP AND SUSTAINABILITY ISSUES}

ISSN 2345-0282 (online) http://jssidoi.org/jesi/ 2020 Volume 8 Number 1 (September) http://doi.org/10.9770/jesi.2020.8.1(56)

and workplaces relative to residential areas. The highest correction among selected variables relative to residential area is represented by workplace and parks variables which are $74 \%$ and $76 \%$ respectively. Taking in consideration those variable along with the level of education (education index of a country) since countries with relatively high education index would stay less at home compared with those countries with relatively lower level of education would have more effective government policy. For example, government should consider leaving grocery and pharmacy shops open since it will not have a significate impact for people to stay at home. However, legislatures should design policies that encourage working at home along with closure of parks. Having these steps in place would increase the percentage of people staying at home and eventually decrease the spread of COVID-19.

Table 3. Correlation matrix of selected variables

\begin{tabular}{|l|c|c|c|c|c|c|}
\hline & Retail \& Recreation & Grocery \& Pharmacy & Parks & Transit station & Workplaces & Residential \\
\hline Retail \& Recreation & 1.00 & & & & & \\
\hline Grocery \& Pharmacy & 0.89 & 1.00 & & & & \\
\hline Parks & 0.74 & 0.67 & 1.00 & & & \\
\hline Transit station & 0.88 & 0.78 & 0.74 & 1.00 & & \\
\hline Workplaces & 0.89 & 0.78 & 0.70 & 0.86 & 1.00 & \\
\hline Residential & -0.68 & -0.64 & -0.76 & -0.72 & -0.74 & 1.00 \\
\hline
\end{tabular}

Source: Compiled by the authors

\section{Conclusions}

During COVID-19 pandemic, policy makers across the world are trying to design the best policy to tackle and minimize the social-economic effect and to increase the percentage of people staying at home to limit the spread of the virus. Countries varies in the implementations depending on their evaluation of the situations and their economical status, that's motivate us to investigate which of the two variables education or real GDP per capita were significate in implementing lockdown and isolation. Many countries have different level of real GDP per capita and education. Using google mobility trends across 123 countries, the study showed that only the level of education can have a negative significate effect on the percentage of people staying at home. The inverse relation between staying at home and education might be related to the political trust in developed countries where less people trust their governments which is confirmed in other studies like (Chevalier, 2019). However, there are other factors that can increase the percentage of individuals staying at home. Limiting and closing parks would have a significate increase the percentage of people staying at home. Also, increasing the percentage of people working at home have a significate positive impact on the percentage of people stayed at home. Other sectors are tested in the study which includes retail, recreation, grocery, pharmacy and transit station but they were not a significate contributor in increasing the percentage of people staying at home.

This study can help policy makers around the world to tailor policies that target workplaces and parks to increase the percentage of people staying at home. Having more individuals works from home along with parks closure would significate increase the level of people staying at home. Also, countries with high level of education index should expect relatively less effective policy implementation compared to countries with lower education index. However, further research is needed as more data feeds in to construct a panel data when this pandemic is ended. Moreover, some countries such as China, Iran and Russia are not included since google services are not offered in them. In order to have a better understanding additional analysis is needed, understanding of economics impact of ineffectual diseases including COVID-19 is vital. Another area of research can be to check and see which business sectors are most affected -positively or negatively- from this pandemic. 


\section{ENTREPRENEURSHIP AND SUSTAINABILITY ISSUES}

ISSN 2345-0282 (online) http://jssidoi.org/jesi/ 2020 Volume 8 Number 1 (September)

http://doi.org/10.9770/jesi.2020.8.1(56)

\section{References}

Abdelhafiz, A. S., Mohammed, Z., Ibrahim, M. E., Ziady, H. H., Alorabi, M., Ayyad, M., \& Sultan, E. A. (2020). Knowledge, Perceptions, and Attitude of Egyptians Towards the Novel Coronavirus Disease (COVID-19). Journal of community health, 1-10. Advance online publication. https://doi.org/10.1007/s10900-020-00827-7

Ayittey, F. K., Ayittey, M. K., Chiwero, N. B., Kamasah, J. S., \& Dzuvor, C. (2020). Economic impacts of wuhan 2019-nCoV on china and the world. Journal of Medical Virology, 92(5), 473-475. https://doi.org/10.1002/jmv.25706

Barua, S. (2020). Understanding coronanomics: the economic implications of the coronavirus (COVID-19) pandemic. Ssrn Electronic Journal, (2020). https://doi.org/10.2139/ssrn.3566477

Chevalier, T. (2019). Political trust, young people and institutions in Europe. a multilevel analysis. International Journal of Social Welfare, 28(4), 418-430. https://doi:10.1111/ijsw.12380

Córdova-Villalobos José A, Sarti, E., Arzoz-Padrés Jacqueline, Manuell-Lee, G., Méndez Josefina Romero, \& Kuri-Morales, P. (2009). The influenza a(H1N1) epidemic in mexico. lessons learned. Health Research Policy \& Systems, 7.

Coronavirus disease $2019 \quad$ (COVID-19) situation $\quad$ report $\quad$-72. $\quad(2020, \quad$ April $\quad 1) \quad$ Retrieved from https://apps.who.int/iris/bitstream/handle/10665/331685/nCoVsitrep01Apr2020-eng.pdf

CSIS (2020). The Global Economic Impacts of COVID-19. (2020, March 10). Retrieved from https://www.csis.org/analysis/globaleconomic-impacts-covid-19

DOL (2020). News release. (2020, April 10). Retrieved from https://www.dol.gov/ui/data.pdf

Evans, D, \& Over, M. (2020). Center for Global Development. Retrieved from https://www.cgdev.org/blog/economic-impact-covid-19low-and-middle-income-countries

Fernandes, N. (2020). Economic effects of coronavirus outbreak (COVID-19) on the world economy. Ssrn Electronic Journal, (2020). https://doi.org/10.2139/ssrn.3557504

Google (2020). COVID-19 community mobility reports. (2020, April 1). Retrieved from https://www.google.com/covid19/mobility

Grossman M (1972) The demand for health: a theoretical and empirical investigation. NBER, New York Iwasaki I, Suganuma K (2015) Foreign direct investment and regional economic development in Russia: an econometric assessment. Econ Change Restruct 48:209-255. https://doi.org/10.1007/s10644-015-9161-y

Khaled Elmawazini \& Pranlal Manga \& Sonny Nwankwo \& Bader AlNaser, 2019. "Health gap between developed and developing countries: Does globalization matter?," Economic Change and Restructuring, Springer, vol. 52(2), pages 123-138, May

Li, K., Qin, Y., Wu, J., \& Yan, J. (2020). Containing the virus or reviving the economy? evidence from individual expectations during the covid-19 epidemic. Ssrn Electronic Journal, (2020). https://doi.org/10.2139/ssrn.3563597

Liang, W., Feng, L., Xu, C., Xiang, N., Zhang, Y., Shu, Y., ... Yang, W. (2012). Response to the first wave of pandemic (H1N1) 2009: experiences and lessons learnt from China. Public Health, 126(5), 427-436. https://doi.org/10.1016/j.puhe.2012.02.008

Liu, S., Wu, P., \& Huang, T. (2018). Nonlinear causality between education and health: The role of human development index. Applied Research in Quality of Life: The Official Journal of the International Society for Quality-Of-Life Studies, 13(3), 761-777. https://doi:10.1007/s11482-017-9557-0 


\section{ENTREPRENEURSHIP AND SUSTAINABILITY ISSUES}

ISSN 2345-0282 (online) http://jssidoi.org/jesi/ 2020 Volume 8 Number 1 (September) http://doi.org/10.9770/jesi.2020.8.1(56)

Lloyd-Smith, J. O., Schreiber, S. J., Kopp, P. E., \& Getz, W. M. (2005). Superspreading and the effect of individual variation on disease emergence. Nature, 438(7066), 355-359. https://doi.org/10.1038/nature04153

Morin, B.R., A. Kinzig, S. Levin, and C. Perrings (2017) Economic incentives in the socially optimal management of infectious disease: When $r_{-}\{0\}$ is not enough, EcoHealth, pages 1-16, 2017.

OECD (2020), OECD Economic Outlook, Interim Report March 2020, OECD Publishing, Paris, https://doi.org/10.1787/7969896b-en. Prager, F., Wei, D., \& Rose, A. (2017). Total economic consequences of an influenza outbreak in the united states: economic consequences of influenza. Risk Analysis, 37(1), 4-19. https://doi.org/10.1111/risa.12625

PwC. 2020. Impact of trade-disrupting COVID-19 on South African business. (2020, February, 20) Retrieved from https://www.pwc.co.za/en/assets/pdf/impact-of-trade-disrupting-covid-19-on-sa-business.pdf

Rassy, D., \& Smith, R. D. (2013). The economic impact of H1N1 on Mexico's tourist and pork sectors. Health Economics, 22(7), 824-34. https://doi.org/10.1002/hec.2862

Reisz, R., \& Stock, M. (2012). Private higher education and economic development. European Journal of Education, 47(2), 198-212. https://doi.org/10.1111/j.1465-3435.2012.01518.x

Saki Nakamura, Takayo Inayama, Kikuko Hata, Munehiro Matsushita, Masaki Takahashi, Kazuhiro Harada, Takashi Arao, 2016 "Association of household income and education with eating behaviors in Japanese adults: a cross-sectional study BMC Public Health"; 16: 61. Published online 2016 Jan 22. https://doi.org/10.1186/s12889-016-2748-z PMCID: PMC4722662

Sands, P., El Turabi, A., Saynisch, P. A., \& Dzau, V. J. (2016). Assessment of economic vulnerability to infectious disease crises. The Lancet, 388(10058), 2443-2448. https://doi.org/10.1016/S0140-6736(16)30594-3

Setia, M. S. (2016). Methodology series module 3: cross-sectional studies. Indian Journal of Dermatology, 61(3), 261-4. https://doi.org/10.4103/0019-5154.182410

Sherpa, D. (2020). Estimating impact of austerity policies in covid-19 fatality rates: examining the dynamics of economic policy and case fatality rates (cfr) of COVID-19 in OECD countries. Ssrn Electronic Journal, (2020). https://doi.org/10.2139/ssrn.3581274

Tracht, S. M., Del Valle, S. Y., \& Edwards, B. K. (2012). Economic analysis of the use of facemasks during pandemic (H1N1) 2009. Journal of Theoretical Biology, 300, 161-172. https://doi.org/10.1016/j.jtbi.2012.01.032

UNDP (2020). The Social and Economic Impact of COVID-19 in the Asia-Pacific Region.. Retrieved from https://www.undp.org/content/undp/en/home/librarypage/crisis-prevention-and-recovery/the-social-and-economic-impact-of-covid-19-inasia-pacific.html

WHO. 2020. Rolling updates on coronavirus disease (COVID-19). Retrieved from https://www.who.int/emergencies/diseases/novelcoronavirus-2019/events-as-they-happen

WHO. 2020. WHO announces COVID-19 outbreak a pandemic. (2020, March 12) Retrieved from http://www.euro.who.int/en/healthtopics/health-emergencies/coronavirus-covid-19/news/news/2020/3/who-announces-covid-19-outbreak-a-pandemic

Zhang, C., Chen, C., Shen, W., Tang, F., Lei, H., Xie, Y.,Du, X. (2020). Impact of population movement on the spread of 2019-nCoV in China. Ssrn Electronic Journal, (2020). https://doi.org/10.2139/ssrn.3546090 


\section{ENTREPRENEURSHIP AND SUSTAINABILITY ISSUES}

ISSN 2345-0282 (online) http://jssidoi.org/jesi/ 2020 Volume 8 Number 1 (September)

http://doi.org/10.9770/jesi.2020.8.1(56)

Hatem AKEEL is an assistant professor of economics and the dean of college of business (CBA) at University of Business and Technology. He leads the college in its mission to create insight and opportunity through unique academic programs that equip students with the skills and knowledge required to become successful leaders and entrepreneurs. He is an economist focusing on global markets, exchanges rates determinations and international finance. He worked as an investment manager of 2 billion Riyal projects before joining academia.

ORCID ID: orcid.org/0000-0003-4854-3189

Haitham KHOJ is an assistant professor of economics and he was a chair department of economics in King Abdul-Aziz University, Jeddah, Saudi Arabia. Recently, he his working as consultant in the research department of the Capital Market Authority in Saudi Arabia. His research interests include Macroeconomics, Financial economics, and International economics.

ORCID ID: orcid.org/0000-0002-7031-3657

Make your research more visible, join the Twitter account of ENTREPRENEURSHIP AND SUSTAINABILITY ISSUES: @Entrepr69728810

Copyright (C) 2020 by author(s) and VsI Entrepreneurship and Sustainability Center

This work is licensed under the Creative Commons Attribution International License (CC BY).

http://creativecommons.org/licenses/by/4.0/

(c) () Open Access 